\title{
One-Step Thermolysis Synthesis of Divalent Transition Metal Ions Monodoped and Tridoped CdS and ZnS Luminescent Nanomaterials
}

\author{
S. E. Saeed, ${ }^{1,2}$ M. M. S. Abdel-Mottaleb, ${ }^{3}$ and M. S. A. Abdel-Mottaleb ${ }^{2}$ \\ ${ }^{1}$ Department of Forgery and Counterfeiting Research, Forensic Medicine Authority, \\ Ministry of Justice, El-Sayeda Zeinab, Cairo 11461, Egypt \\ ${ }^{2}$ Nanophotochemistry and Solarchemistry Labs, Department of Chemistry, Faculty of Science, \\ Ain Shams University, Abbassia, Cairo 11566, Egypt \\ ${ }^{3}$ Center for Nanotechnology, School of Engineering and Applied Sciences, Nile University, \\ Juhayna Square, Sheikh Zayed, 6th of October City, Giza 12588, Egypt
}

Correspondence should be addressed to M. S. A. Abdel-Mottaleb; phochem08@photoenergy.org

Received 12 May 2014; Revised 30 July 2014; Accepted 31 July 2014; Published 19 August 2014

Academic Editor: Binbin Weng

Copyright (C) 2014 S. E. Saeed et al. This is an open access article distributed under the Creative Commons Attribution License, which permits unrestricted use, distribution, and reproduction in any medium, provided the original work is properly cited.

$\mathrm{Mn}^{2+}, \mathrm{Co}^{2+}$, or $\mathrm{Ni}^{2+}$ monodoped CdS (or $\mathrm{ZnS}$ ) and $\mathrm{Mn}^{2+}-\mathrm{Co}^{2+}-\mathrm{Ni}^{2+}$ tridoped CdS (or $\mathrm{ZnS}$ ) have been successfully synthesized by novel one-step thermolysis method using thiourea as a sulphur source. The synthesized nanomaterials were characterized by $\mathrm{X}$-ray diffraction (XRD), transmission electron microscopy (TEM), and scanning electron microscopy (SEM). It is found that the average diameter and morphology of the synthesized samples varied with the nature of dopant ion. The successful doping of $\mathrm{Mn}^{2+}$ $\mathrm{Co}^{2+}-\mathrm{Ni}^{2+}$ tridoped ions into the host CdS (or ZnS) was proved by the EDX spectra. The luminescence of CdS is only enhanced when monodoped with $\mathrm{Mn}^{2+}$ whereas it is enhanced when $\mathrm{ZnS}$ is either monodoped with $\mathrm{Mn}^{2+}, \mathrm{Co}^{2+}$, or $\mathrm{Ni}^{2+}$ or tridoped with $\mathrm{Mn}^{2+}-\mathrm{Co}^{2+}-\mathrm{Ni}^{2+}$. The synthesized samples could therefore offer opportunities for further fundamental research and technological applications.

\section{Introduction}

In recent years, II-VI semiconductors have been attracting increasing attention due to their excellent prospective use as optoelectronic devices [1], solar cells [2], light-emitting diodes [3], quantum dots [4], photocatalyst [5], drug delivery $[6,7]$, and multicolor fluorescent markers in biological systems [8], in magnetic functionality $[9,10]$. Among these semiconductors, $\mathrm{CdS}$ and $\mathrm{ZnS}$ have wide band gap energy of 2.42 and $3.68 \mathrm{eV}$, respectively $[11,12]$.

Zinc sulfide is chemically stable and characterized by low toxicity and large band gap compared with other chalcogenides such as $\mathrm{ZnSe}$ and $\mathrm{ZnO}[13,14]$. $\mathrm{ZnS}$ has been used widely as an important phosphor for photoluminescence (PL), electroluminescence (EL), and cathodoluminescence (CL) devices [15].
CdS powder is of potential applications in the production of light sources emitting in the green region, in the technology of solar cells and photocells [16] as well as laser screen materials, projection color TVs, and nuclear radiation detectors [17-19].

In addition, $\mathrm{CdS}$ and $\mathrm{ZnS}$ are suitable for use as host materials for a variety of dopants because of their wide band gap. The doping of metal ions in CdS or ZnS has led to unique optical, electrical, chemical, and mechanical properties, which cannot be found in the undoped materials [20]. Transition metal ions are the most interesting impurities as they introduce deep levels in the gap region, which can influence not only the optical characteristics but also the electrical and magnetic properties, influencing their practical applications [21]. 


$$
\begin{array}{ll}
\mathrm{Cd}\left(\mathrm{CH}_{3} \mathrm{COO}\right)_{2} \cdot 2 \mathrm{H}_{2} \mathrm{O} & \mathrm{CdS}: \mathrm{M}^{* 2+}+\mathrm{CO}_{2}+\mathrm{CH}_{4} \\
+\mathrm{M}^{*}\left(\mathrm{NO}_{3}\right)_{2} \cdot \mathrm{YH}_{2} \mathrm{O} & + \text { Steam } \uparrow+\mathrm{O}_{2} \uparrow+\mathrm{NO}_{2} \uparrow \\
+\mathrm{NH}_{2} \mathrm{CSNH}_{2} &
\end{array}
$$

Scheme 1: Proposed mechanism for metal ion doped CdS formation where $\mathrm{M}^{*}$ is $\mathrm{Ni}, \mathrm{Co}$, or $\mathrm{Mn}$ ions and $\mathrm{Y}$ is the number of water molecules.

Doping of CdS or ZnS nanoparticles by transition metal ions, for example, $\mathrm{Mn}^{2+}[22], \mathrm{Co}^{2+}[23]$, and $\mathrm{Ni}^{2+}[24$, 25], has been successfully done by techniques such as thermal evaporation, sol-gel processing, coprecipitation, and microemulsions. Most of these techniques have several steps and are not cost effective [26-35].

The simultaneous presence of two kinds of defects known as codoping can lead to remarkable change of the semiconductor properties such as photoluminescence properties [36] and magnetic properties [37-39].

There are limited studies on synthesis and luminescence of codoped CdS [25, 40] and codoped ZnS [36, 41-45]. Moreover, there are some studies reported on tridoped $\mathrm{ZnO}$ [46] and tridoped $\mathrm{TiO}_{2}$ [47-49].

To the best of our knowledge, there are no reported studies on synthesis and luminescence of tridoped CdS or tridoped $\mathrm{ZnS}$. This prompted us to tackle the problem of one-step synthesis of tridoped CdS and $\mathrm{ZnS}$ and their characteristic luminesce for possible exploitation as tagging materials.

\section{Experimental}

2.1. Materials. Zinc (II) nitrate hexahydrate, cadmium (II) acetate dehydrate, manganese (II) tetrahydrate, cobalt (II) nitrate hexahydrate, and nickel (II) nitrate hexahydrate were obtained from Sigma-Aldrich. Ethyl alcohol was laboratory grade chemical. All the reagents were used without further purification.

2.2. Methods. Nanometal ions doped CdS was prepared by cadmium-thiourea complex thermolysis route at $200^{\circ} \mathrm{C}$ (see Scheme 1).

To prepare $\mathrm{Mn}^{2+} 10 \%$ CdS nanomaterials, the stoichiometric ratio of cadmium (II) acetate dehydrate, manganese (II) nitrate tetrahydrate, and thiourea were taken as $1: 0.1: 2$. In this method, the powder solid materials of $0.01 \mathrm{~mol}$ cadmium (II) acetate dihydrate, 0.001 manganese (II) nitrate tetrahydrate, and $0.02 \mathrm{~mol}$ thiourea were mixed in a crucible and transferred into oven at $200^{\circ} \mathrm{C}$ for 2 hours. The product was collected and washed with distilled water and then ethanol. Finally it dried at $80^{\circ} \mathrm{C}$ for 1 hour.

Other metal ions $\left(\mathrm{Ni}^{2+}\right.$ or $\left.\mathrm{Co}^{2+}\right)$ monodoped $\mathrm{CdS}$ was prepared according to the above procedure.

$\mathrm{Mn}^{2+}-\mathrm{Co}^{2+}-\mathrm{Ni}^{2+}$ tridoped CdS was prepared according to the above procedure by mixing $0.01 \mathrm{~mol}$ cadmium (II) acetate dehydrate, $0.001 \mathrm{~mol}$ of manganese (II) nitrate tetrahydrate, cobalt (II) nitrate hexahydrate, nickel nitrate (II) hexahydrate, and 0.02 mol thiourea and transferred into oven according to the above procedure.

$$
\begin{array}{lll}
\mathrm{Zn}\left(\mathrm{NO}_{3}\right)_{2 \cdot 6} \mathrm{H}_{2} \mathrm{O} & 200^{\circ} \mathrm{C} & \mathrm{Zn} \mathrm{S:M} \mathrm{M}^{* 2+} \downarrow+\mathrm{CO}_{2} \uparrow+\mathrm{CH}_{4} \uparrow \\
+\mathrm{M}^{*}\left(\mathrm{NO}_{3}\right)_{2} \cdot \mathrm{YH}_{2} \mathrm{O} & & + \text { Steam } \uparrow+\mathrm{O}_{2} \uparrow+\mathrm{NO}_{2} \uparrow \\
+\mathrm{NH}_{2} \mathrm{CSNH}_{2} &
\end{array}
$$

Scheme 2: Proposed mechanism for metal ion doped $\mathrm{ZnS}$ formation.

Pure CdS was also prepared in the same way.

Transition metal ions doped $\mathrm{ZnS}, \mathrm{Mn}^{2+}-\mathrm{Co}^{2+}-\mathrm{Ni}^{2+}$ tridoped $\mathrm{ZnS}$, and pure $\mathrm{ZnS}$ were prepared by zinc-thiourea complex thermolysis route at $200^{\circ} \mathrm{C}$. The synthetic procedure is identical to that of $\mathrm{CdS}$ by using zinc (II) nitrate hexahydrate instated of cadmium (II) acetate dehydrate (see Scheme 2).

2.3. Instrumentation. Identification of the crystal phases was conducted by X-ray diffraction analysis. The X-ray diffraction (XRD) patterns were obtained by using a Bruker-AXS D8 Advance, with $\mathrm{Ni}$ filtered $\mathrm{Cu} \mathrm{K} \alpha$ radiation in the range of $2 \theta$ from $4^{\circ}-60^{\circ}$. The reference data for the interpretation of the XRD patterns were obtained from the Joint Committee on Powder Diffraction Standards (JCPDS) files.

The grain size was determined from the $\mathrm{X}$-ray diffraction patterns using the Scherrer formula $(G=\lambda / D \cos \theta)$, where $G$ is the grain size, $\lambda$ is the wavelength of the X-rays (1.5418), $D$ is the width of the peak at half maximum, and $\theta$ is the angle of incidence of X-ray beam.

Electron microscopy studies were undertaken using transmission electron microscopy (TEM) (JEOL JEM-1230, with an accelerating voltage of 40-120 KV) and scanning electron microscopy (SEM) (JEOL JXA-840A Electron Probe Microanalyzer, using an accelerating voltage of $30 \mathrm{KV}$ ) with an attached energy dispersive X-ray spectrometer (EDX). EDX measurements were acquired at a number of points in the samples. SEM samples were prepared on an appropriate disk and coated with gold to make the samples conductive to electrons.

Luminescence spectra were measured in the range 254800 nm using a Perkin Elmer LS 55. Perken Elmer LS 55-PC Spectroflurophotometer (with $3 \mathrm{~nm}$ excitation and emission slid width).

\section{Results and Discussion}

3.1. Structure Morphology. Figure 1 shows the XRD data of $\mathrm{CdS}$ and metal ions doped CdS. All the diffraction peaks of metal ions doped CdS are consistent with the values of the standard (JCPDS card number 41-1049) and can be indexed to pure hexagonal CdS structure (Figure 1).

In addition, no secondary phase is detected in the XRD patterns which illustrates that the obtained products arrays are highly pure and single phase crystal. Peaks at $2 \theta \approx 24.8^{\circ}$, $26.4^{\circ}, 28.1^{\circ}, 36.6^{\circ}, 43.6^{\circ}, 47.8^{\circ}$, and $51.8^{\circ}$ are attributed to (100), (002), (101), (102), (110), (103), and (112) CdS planes, respectively.

As shown in Figure 1, XRD peak broadening indicates the small size of the obtained CdS and metal ions doped CdS 


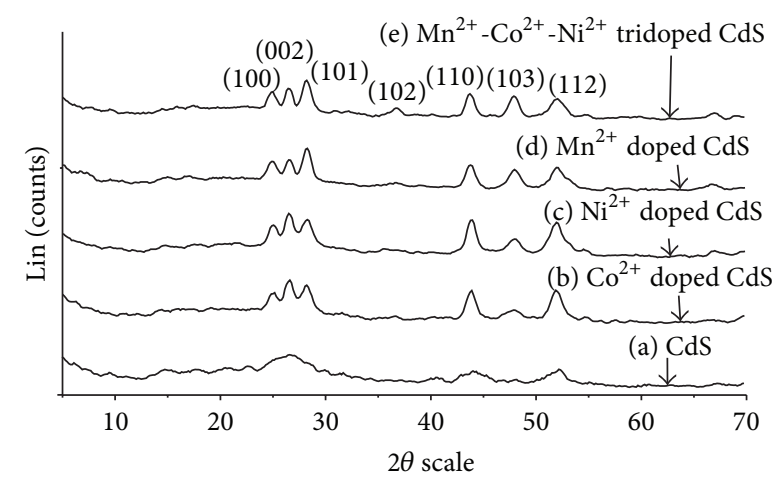

FIgURE 1: XRD of (a) CdS, (b) $\mathrm{Co}^{2+}$ doped CdS, (c) $\mathrm{Ni}^{2+}$ doped CdS, (d) $\mathrm{Mn}^{2+}$ doped CdS, and (e) $\mathrm{Mn}^{2+}-\mathrm{Co}^{2+}-\mathrm{Ni}^{2+}$ tridoped CdS.

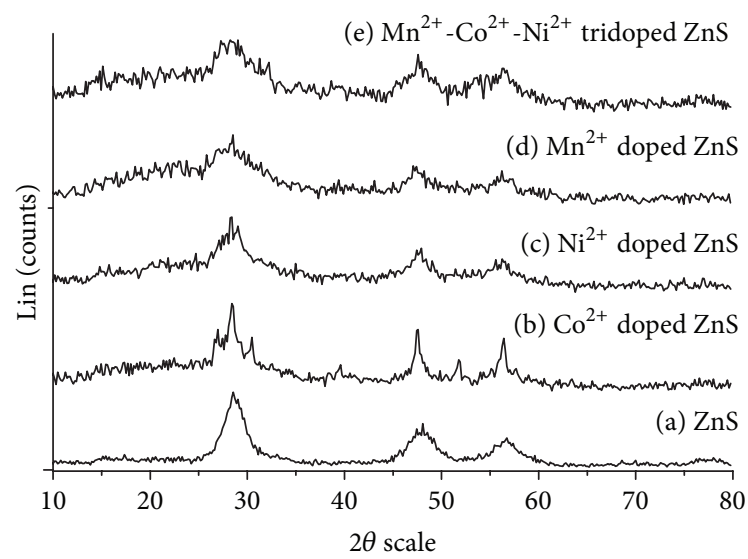

Figure 2: XRD of (a) ZnS, (b) $\mathrm{Co}^{2+}$ doped $\mathrm{ZnS}$, (c) $\mathrm{Ni}^{2+}$ doped $\mathrm{ZnS}$, (d) $\mathrm{Mn}^{2+}$ doped $\mathrm{ZnS}$, and (e) $\mathrm{Mn}^{2+}-\mathrm{Co}^{2+}-\mathrm{Ni}^{2+}$ tridoped $\mathrm{ZnS}$.

nanocrystals. XRD patterns show the very broad and wide peaks of pure CdS (Figure 1-(a)). In case of dopant metal ion, it could be observed that XRD peaks get sharper (Figure 1-(b), Figure 1-(e)) indicating that nanocrystal size is larger when grown in the presence of dopant ions [50].

The XRD pattern of Figure 2 shows three strong diffraction peaks with $2 \theta \approx$ values of $28.71^{\circ}, 48.19^{\circ}$, and $56.78^{\circ}$ which appear due to reflection from the (008), (110), and (118) planes of hexagonal zinc sulphide. All the diffraction peaks of metal ions doped $\mathrm{ZnS}$ are consistent with the values of the standard (JCPDS card number 39-1363) and can be indexed to pure hexagonal $\mathrm{ZnS}$ structure.

We also observed the typical broadening of the peaks indicating very small size of the synthesized $\mathrm{ZnS}$ and metal ions doped ZnS particles [51].

From XRD patterns, it can be found that the positions of diffraction peaks slightly shift with metal ion doped CdS or $\mathrm{ZnS}$, reflecting the $d$ values changes due to ionic radii difference between the dopant ion and the host (cadmium or zinc) ion. The ionic radii of $\mathrm{Cd}^{+2}, \mathrm{Zn}^{+2}, \mathrm{Mn}^{2+}, \mathrm{Co}^{2+}$, and $\mathrm{Ni}^{+2}$ are $0.095,0.074,0.083,0.069$, and $0.065 \mathrm{~nm}$, respectively [52]. All of the dopant ions are smaller than the host $\mathrm{Cd}^{+2}$ or $\mathrm{Zn}^{+2}$ ions except $\mathrm{Mn}^{2+}$ relative to $\mathrm{Zn}^{+2}$, suggesting that, at this slightly large doping ratio (10\%), the dopant metal ion

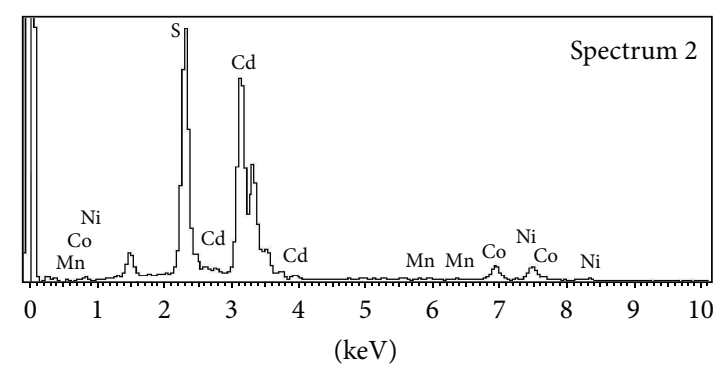

Full scale 2076 cts cursor: 0.013 (17217 cts)

Figure 3: EDX spectrum for $10 \% \mathrm{Mn}^{2+}-\mathrm{Co}^{2+}-\mathrm{Ni}^{2+}$ tridoped CdS nanoparticles.

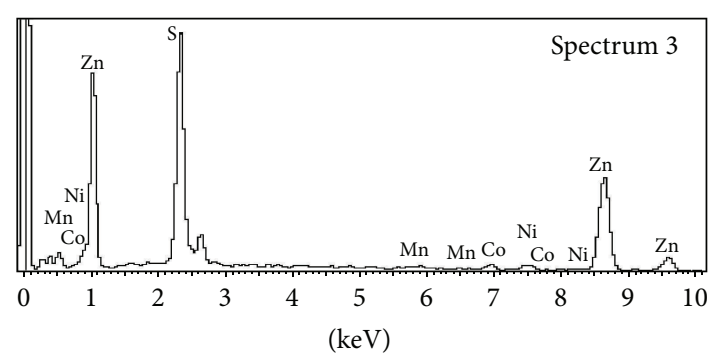

Full scale 2076 cts cursor: 0.013 (17331 cts)

FIGURE 4: EDX spectrum of the synthesized $10 \% \mathrm{Mn}^{2+}-\mathrm{Co}^{2+}-\mathrm{Ni}^{2+}$ tridoped $\mathrm{ZnS}$ nanoparticles.

enters to the lattice substitutionary interstitially leading to increasing the interplaner spacing $(d)$ values (see Tables 1 and 2) [53]. $\mathrm{Mn}^{2+}$ dopant ion is larger than $\mathrm{Zn}^{+2}$, so manganese replaced some of the zinc atoms leading to increasing $d$ values [44].

The possible chemical reaction that takes place on the heated substances to produce CdS could be as follows $[53,54]$. Thiourea dissociates and releases $\mathrm{S}^{2-}$; the cadmium acetate or zinc nitrate was believed to be interlinked by sulfide atom. In consecutive step, the $\mathrm{C}-\mathrm{S}$ bond of sulfide source molecule breaking and the simultaneous formation of $\mathrm{Cd}-\mathrm{S}$ or $\mathrm{Zn}-\mathrm{S}$ bond, resulting in the growth of $\mathrm{CdS}$ or $\mathrm{ZnS}$ nanomaterials $[55,56]$.

The successful doping of $\mathrm{Mn}^{+2}-\mathrm{Co}^{+2}-\mathrm{Ni}^{+2}$ tridoped ions into the host (CdS or $\mathrm{ZnS}$ ) can be proved by energy dispersive $\mathrm{X}$-ray spectrometer (EDX) spectra.

As shown in Figures 3 and 4 as well as Tables 3 and 4, EDX spectra indicate that the finger print signals for (cadmium or zinc), sulfur, manganese, cobalt, and nickel elements were observed.

As shown in Tables 3 and 4, the elements atomics \% of cadmium, sulfur, manganese, cobalt, and nickel are 37.98 , $53.17,0.3,4.34$, and 4.2 , respectively. The elemental atomics $\%$ of zinc, sulfur, manganese, cobalt, and nickel are 38.72, 58.41, $0.29,1.39$, and 1.19 , respectively. It should be noted that the dopant manganese atomic ratio in tridoped CdS or tridoped $\mathrm{ZnS}$ is very small compared with that of nickel and cobalt.

For $\mathrm{Mn}^{+2}-\mathrm{Co}^{+2}-\mathrm{Ni}^{+2}$ tridoped CdS or tridoped $\mathrm{ZnS}$ the dopant ions are assumed to substitute the host ( $\mathrm{Zn}$ or $\mathrm{Cd}$ ) ions or to be inserted as interstitial ions. The solubility of MnS 


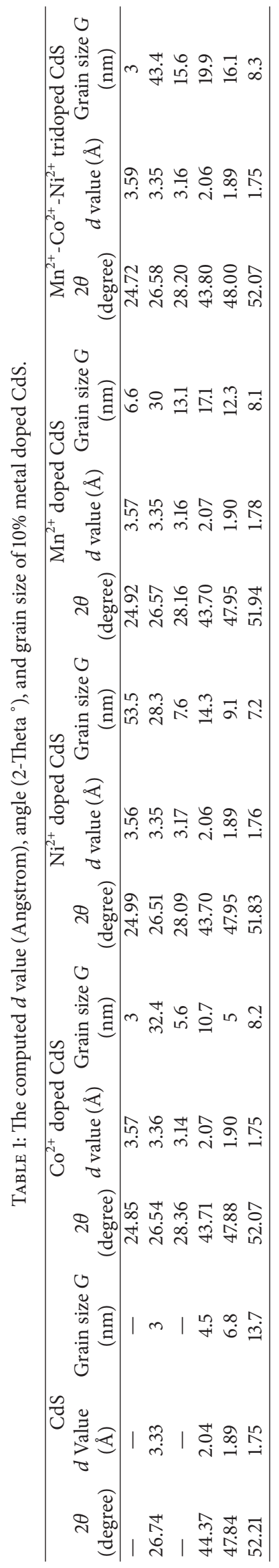




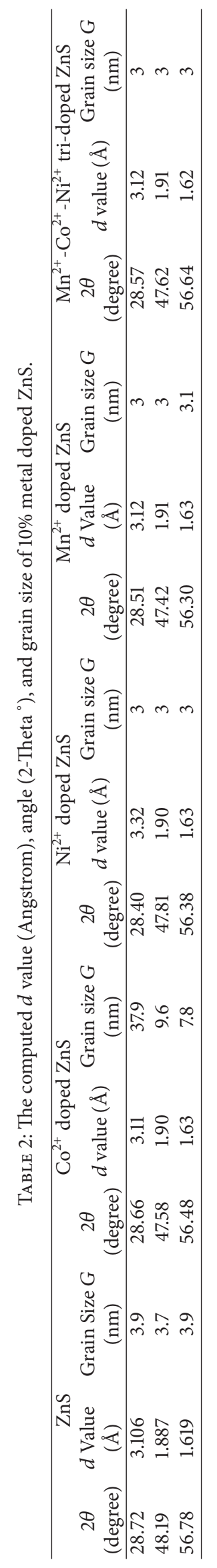


TABLE 3: Elements ratio calculated from EDX results of the synthesized 10\% Mn-Ni-Co-doped CdS nanoparticles.

\begin{tabular}{lcc}
\hline Element & Weight\% & Atomic\% \\
\hline S K & 26.26 & 53.17 \\
Mn K & 0.26 & 0.30 \\
Co K & 3.94 & 4.34 \\
Ni K & 3.80 & 4.20 \\
Cd L & 65.75 & 37.98 \\
\hline Totals & 100.00 & 100.00 \\
\hline
\end{tabular}

TABLE 4: Elements ratio calculated from EDX results of the synthesized $10 \% \mathrm{Mn}-\mathrm{Ni}$-Co-doped $\mathrm{ZnS}$ nanoparticles.

\begin{tabular}{lcc}
\hline Element & Weight\% & Atomic\% \\
\hline S K & 40.96 & 58.41 \\
Mn K & 0.35 & 0.29 \\
Co K & 1.80 & 1.39 \\
Ni K & 1.53 & 1.19 \\
Zn K & 55.36 & 38.72 \\
\hline Totals & 100.00 & 100.00 \\
\hline
\end{tabular}

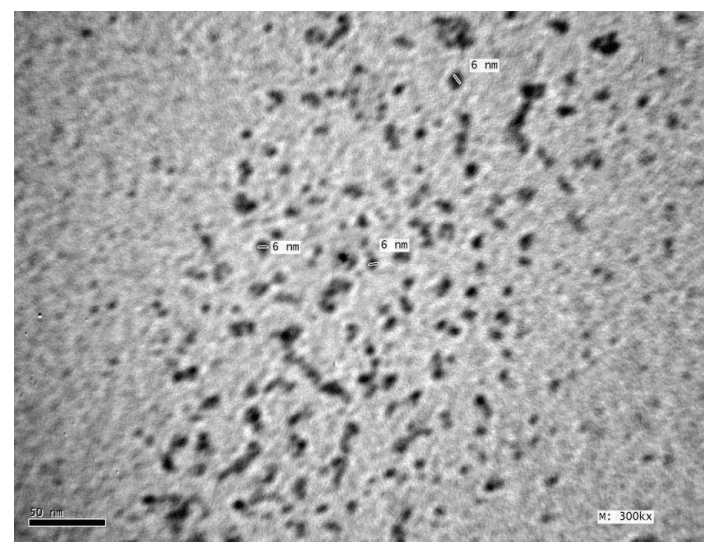

FIGURE 5: TEM picture of pure undoped CdS at a magnification of $300 \mathrm{KX}$.

$\left(k_{\mathrm{SP}} \sim 10^{-10}\right)$ is far higher than that of NiS $\left(k_{\mathrm{SP}} \sim 10^{-19}\right)$, CoS $\left(k_{\mathrm{SP}} \sim 10^{-21}\right)$, ZnS $\left(k_{\mathrm{SP}} \sim 10^{-22}\right)$, and CdS $\left(k_{\mathrm{SP}} \sim 10^{-27}\right)$ [57]. Species having higher solubility in water precipitate more difficultly and so $\mathrm{Co}^{2+}$ and $\mathrm{Ni}^{2+}$ ions can easily displace $\mathrm{Cd}^{2+}$ or $\mathrm{Zn}^{2+}$ of the host lattice. $\mathrm{MnS}$ is far more higher soluble than $\mathrm{CdS}$ or $\mathrm{ZnS}$. Thus, $\mathrm{Mn}^{+2}$ is much less efficient at displacing $\mathrm{Cd}^{+2}$ or $\mathrm{Zn}^{+2}$ of the host lattice.

The ionic radii of $\mathrm{Cd}^{+2}, \mathrm{Zn}^{2+}, \mathrm{Mn}^{2+}, \mathrm{Co}^{2+}$, and $\mathrm{Ni}^{+2}$ are $0.095 \mathrm{~nm}, 0.074 \mathrm{~nm}, 0.083 \mathrm{~nm}, 0.069 \mathrm{~nm}$, and $0.065 \mathrm{~nm}$, respectively [52]. The $\mathrm{Co}$ and $\mathrm{Ni}$ dopant ions are smaller than that of $\mathrm{Mn}$. This results in ease substitution of $\mathrm{Zn}$ ions by Co and $\mathrm{Ni}$ ions or to be inserted as interstitial ions.

As can be seen from figure 5, pure CdS nanoparticles have an average diameter of $6 \mathrm{~nm}$. On the other hand, in the presence of dopant ions, the particle size of the samples increases (Figures 5, 6, 7, 8, 9, 10, 11, 12 and 13) (see Tables 1

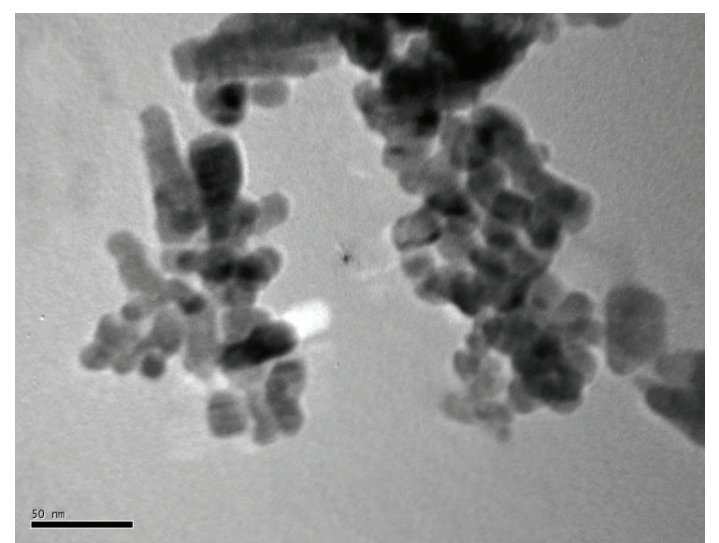

FIGURE 6: TEM picture of $\mathrm{Co}^{2+}$ doped CdS at a magnification of $400 \mathrm{KX}$.

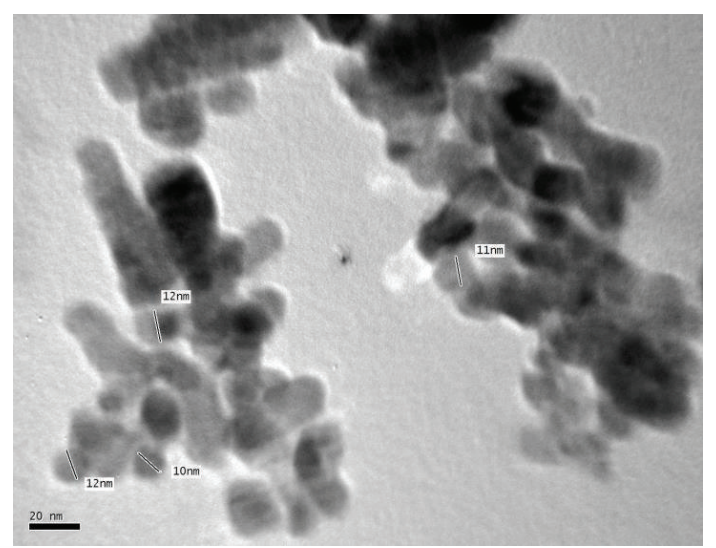

Figure 7: TEM picture of pure $\mathrm{Co}^{2+}$ doped $\mathrm{CdS}$ at a magnification of $600 \mathrm{KX}$.

and 2), which is corroborated with the XRD results. Because the dopant metal ions are small, they can easily occupy the substitutional sites as well as the interstitial sites of the host lattice. The interstitially entrance of dopants leads to the expansion of host lattice and hence particle size increasing. The ion radius of $\mathrm{Mn}^{2+}$ is larger than that of $\mathrm{Co}^{2+}$ and $\mathrm{Ni}^{2+}$ and so it leads to the more expansion of the host lattice and hence $\mathrm{Mn}^{2+}$ doped CdS gave the largest particle size. $\mathrm{Mn}^{2+}$ $\mathrm{Co}^{2+}-\mathrm{Ni}^{2+}$ tridoped $\mathrm{CdS}$ also gave small particle size than $\mathrm{Mn}$ doped CdS. The small ionic radii of $\mathrm{Co}^{+2}$ and $\mathrm{Ni}^{+2}$ in comparison to that of $\mathrm{Mn}^{+2}$, explains the easiest interstitial doping for $\mathrm{Co}^{+2} / \mathrm{Ni}^{+2}$. The doped $\mathrm{CdS}$ forms heterogeneous nano-spheres, which are uniform in morphology and particle size (Figures 6 to 13). As shown in Figures 5 to 13, pure CdS nanoparticles show tendency to disperse as they settle on the carbon coated copper grid (Figure 5). On the other hand, in the presence of dopant metal ions, the samples show tendency to agglomerate as they settle on the carbon coated copper grid (Figures 6 to 13). Aggregation of the doped CdS nanocrystals may be due to the high surface energy of the doped CdS nanocrystals [58]. Metal ions dopants form spherical shape due to the redeposition of ions from $\{001\}$ to the other facets to make an equilibrium spherical shape [6]. 


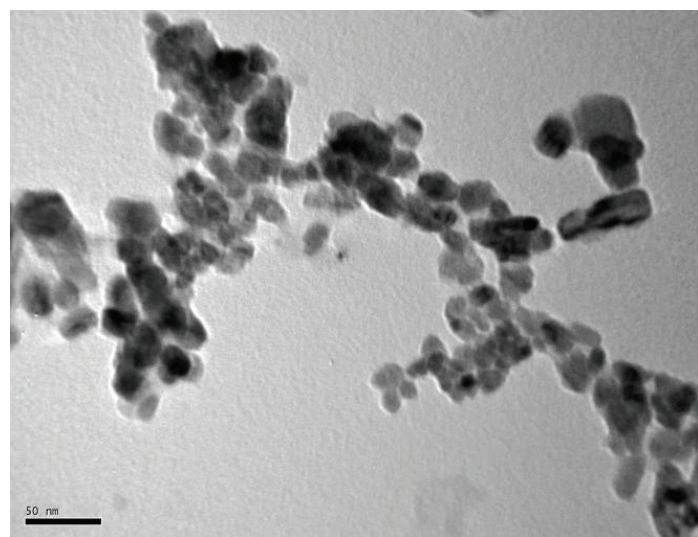

FIGURE 8: TEM picture of $\mathrm{Ni}^{2+}$ doped $\mathrm{CdS}$ at a magnification of $300 \mathrm{KX}$.

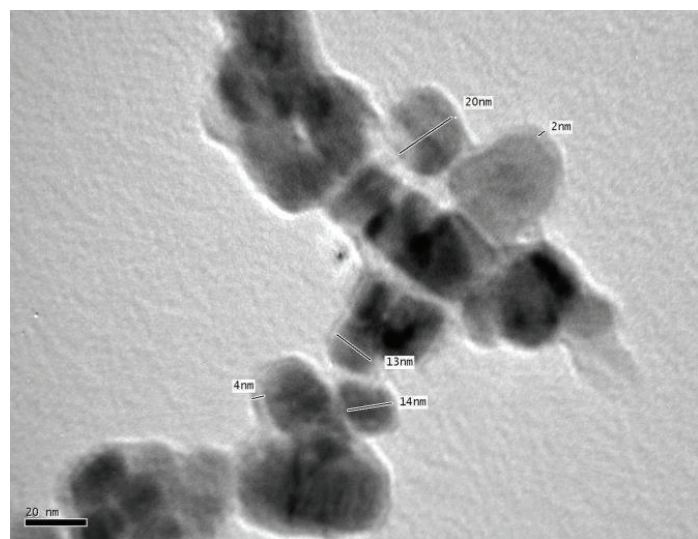

FIGURE 9: TEM picture of $\mathrm{Ni}^{2+}$ doped $\mathrm{CdS}$ at a magnification of $600 \mathrm{KX}$.

As shown in Figures 14, 15, 16, 17, and 18, the $\mathrm{ZnS}$ nanostructured materials with the size of 50-100 nanometers in diameter are obtained. The contrast variations within the image suggest that the spheres are composed of nanocrystallites.

From the TEM micrographs, it is clear that the nanoparticles obtained without doping are quantum dots (Figure 14). On the other hand, in the presence of a dopant ion, the particle size of the samples increased, which is corroborated with the XRD results.

\subsection{Photoluminescence Spectroscopy. Figure 19 shows photo-} luminescence (PL) spectra of doped and undoped CdS. These spectra were recorded in spectral range of 370-650 $\mathrm{nm}$ with an excitation wavelength of $360 \mathrm{~nm}$. The PL spectra of pure $\mathrm{CdS}$ quantum dots have emission peak as shown in Figure 19(a), the corresponding luminescence peaks centered at about $485 \mathrm{~nm}$ originated from the band edge and the broad emission centered at around $530 \mathrm{~nm}$ arises from trap-related recombination from surface defects sites. This emission results from radiative recombination of electrons and holes via the surface defect states present in the nanocrystals [59]. The electrons and holes, after excitation across the band edge,

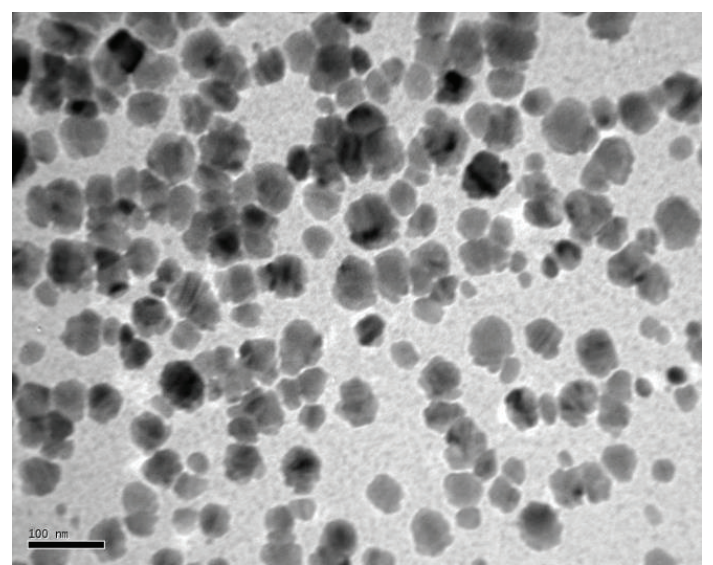

FIgURE 10: TEM picture of $\mathrm{Mn}^{2+}$ doped CdS at a magnification of $150 \mathrm{KX}$.

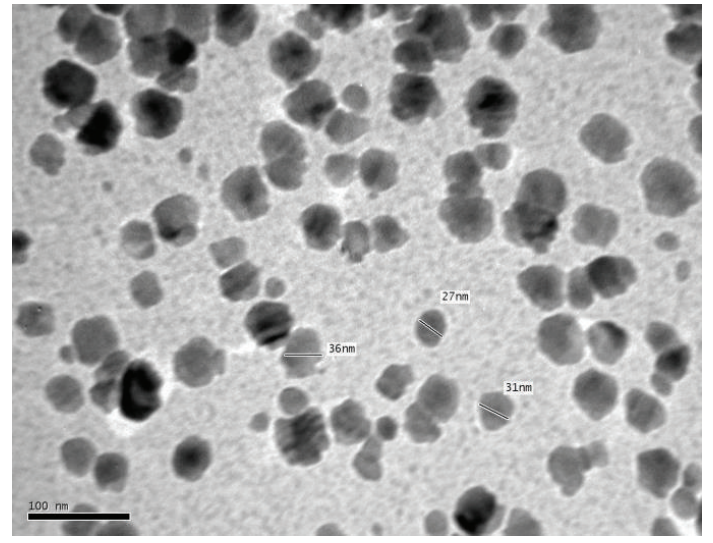

FIGURE 11: TEM picture of $\mathrm{Mn}^{2+}$ doped CdS at a magnification of $300 \mathrm{KX}$

trickle down nonradiatively to the surface states lying in the band gap region. Radiative deexcitation across the surface states in CdS nanocrystals gives rise to bright yellow-green fluorescence observed at around $500 \mathrm{~nm}$ [60].

Luminescence properties of manganese, cadmium, and nickel doped CdS nanocrystals have been mainly studied. The $\mathrm{PL}$ intensity increased in case of $\mathrm{Mn}^{2+}$ and decreased in case of $\mathrm{Co}^{2+}$ and $\mathrm{Ni}^{2+}$. This is due to the fact that the doped $\mathrm{Mn}^{2+}$ ions provide good traps for the excited electrons [60]. The ion radius of $\mathrm{Cd}^{+2}, \mathrm{Mn}^{2+}, \mathrm{Co}^{2+}$, and $\mathrm{Ni}^{+2}$ are $0.095 \mathrm{~nm}, 0.083 \mathrm{~nm}$, $0.069 \mathrm{~nm}$, and $0.065 \mathrm{~nm}$, respectively [52]. Mn, Ni, or Co ions may be in CdS sites as substitutional or as interstitial ions of $\mathrm{CdS}$ nanoparticles. When these ions are doped into the CdS nanoparticles, cadmium ions $(0.095 \mathrm{~nm})$ will be replaced by the smaller $\mathrm{Ni}$ or Co ions in the host lattice and hence $\mathrm{Ni}$ or Co deep centers are formed, which can inhibit more electrons (holes) to be excited and can lead to the enhancement of nonradiative recombination processes. As a result, $\mathrm{Ni}$ and $\mathrm{Co}$ dopant ions emission intensities become weaker than that of pure CdS nanoparticles [61]. Also Ni doped CdS shows (Figure 19-(d)) weaker luminescence than that of codoped $\mathrm{CdS}$ because $\mathrm{Ni}$ ionic radius is smaller than that of $\mathrm{Co}$ and so 


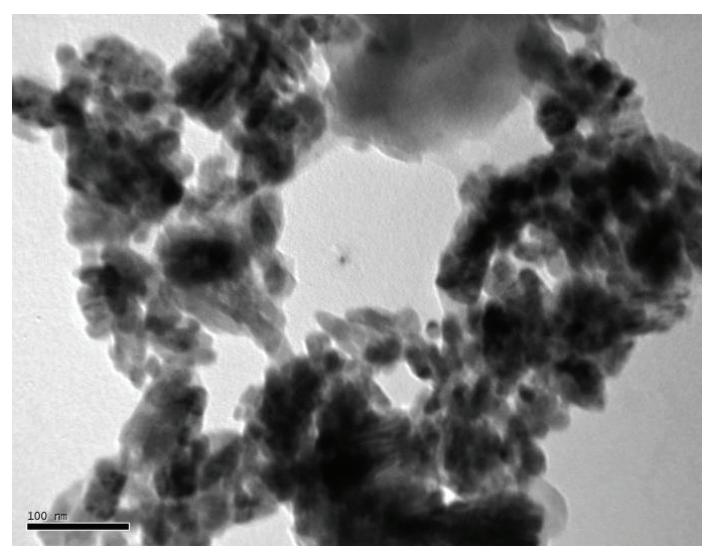

FIGURE 12: TEM picture of $\mathrm{Mn}^{2+}-\mathrm{Co}^{2+}-\mathrm{Ni}^{2+}$ tridoped doped CdS at a magnification of $200 \mathrm{KX}$.

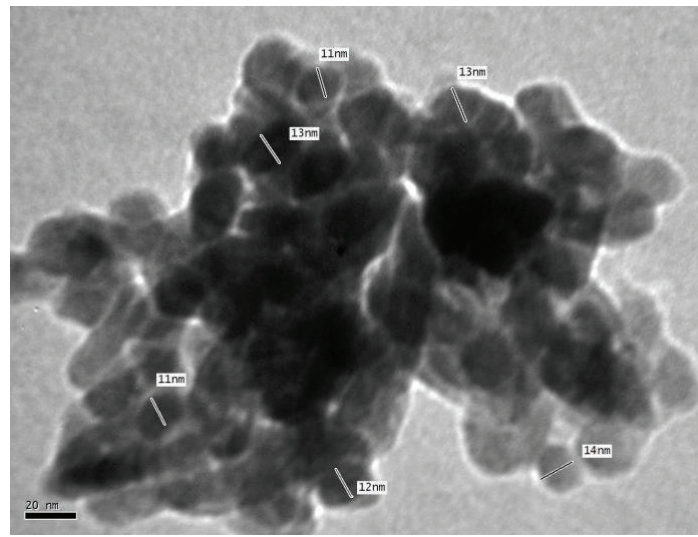

Figure 13: TEM picture of $\mathrm{Mn}^{2+}-\mathrm{Co}^{2+}-\mathrm{Ni}^{2+}$ tridoped CdS at a magnification of $500 \mathrm{KX}$.

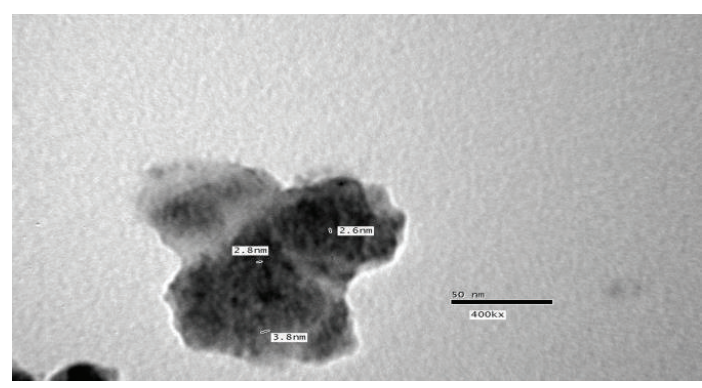

FIGURE 14: TEM picture of pure ZnS $400 \mathrm{KX}$.

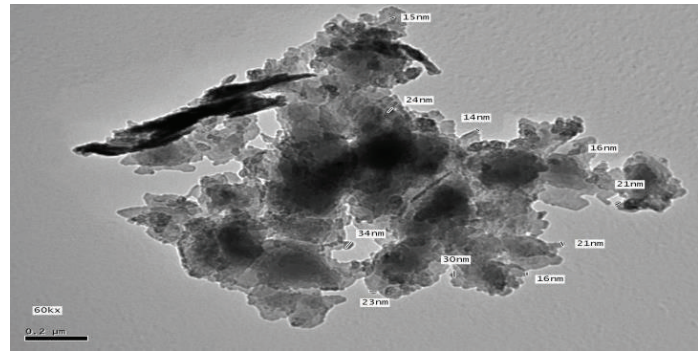

FIGURE 15: TEM picture of $\mathrm{Mn}^{2+}$ doped $\mathrm{ZnS} 60 \mathrm{KX}$.

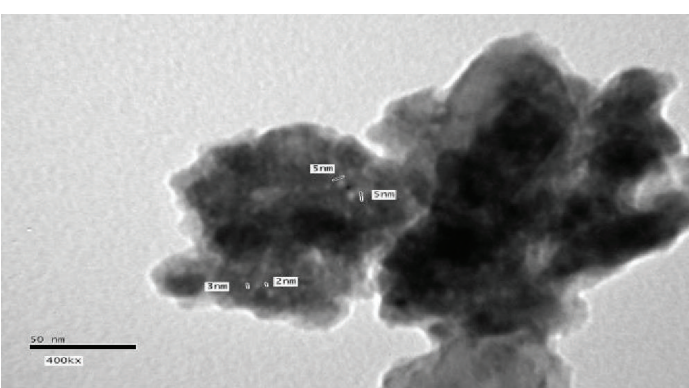

Figure 16: TEM picture of $\mathrm{Co}^{2+}$ doped $\mathrm{ZnS} 400 \mathrm{KX}$.

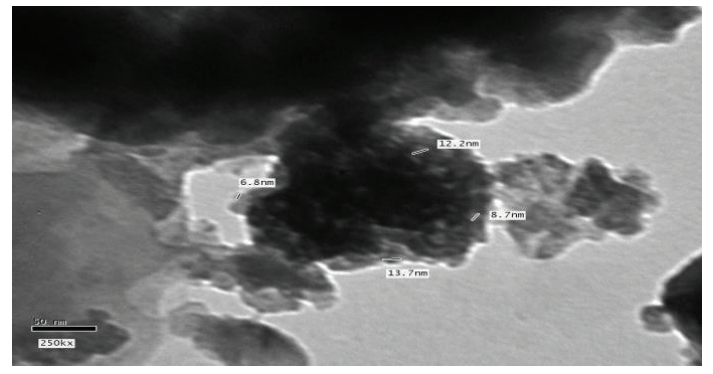

Figure 17: TEM picture of $\mathrm{Ni}^{2+}$ doped $\mathrm{ZnS} 250 \mathrm{KX}$.

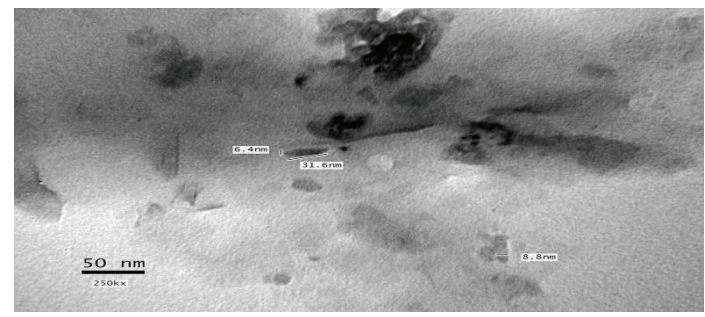

FIgURE 18: TEM picture of $\mathrm{Mn}^{2+}-\mathrm{Co}^{2+}-\mathrm{Ni}^{2+}$ tridoped $\mathrm{ZnS}$ at a magnification of $250 \mathrm{KX}$.

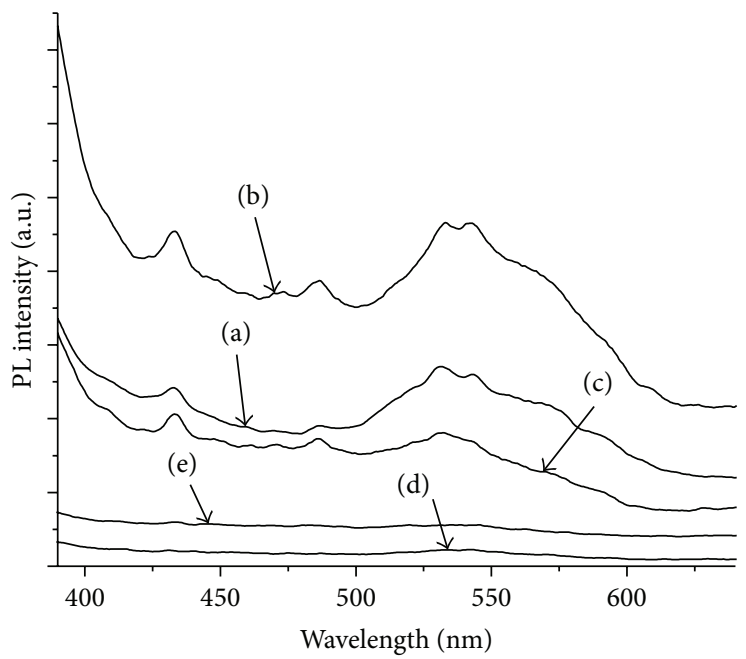
(a) CdS
(d) $\mathrm{Ni}^{2+}$ doped CdS
(b) $\mathrm{Mn}^{2+}$ doped CdS
(e) $\mathrm{Mn}^{2+}-\mathrm{Co}^{2+}-\mathrm{Ni}^{2+}$ tridoped CdS
(c) $\mathrm{Co}^{2+}$ doped $\mathrm{CdS}$

FIGURE 19: PL emission spectra of undoped CdS and 10\% metal ion doped CdS excited at $360 \mathrm{~nm}$. 


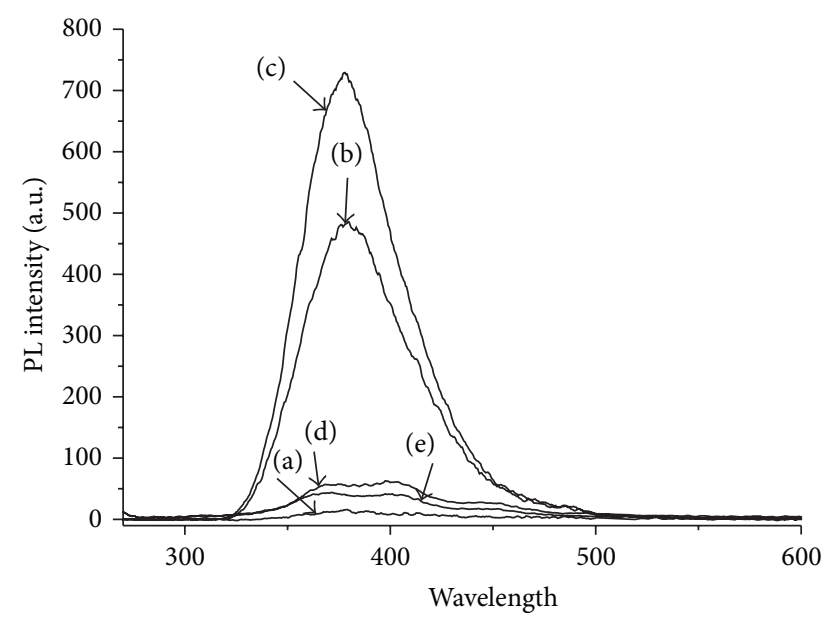
(a) $\mathrm{ZnS}$
(d) $\mathrm{Mn}^{2+}$ doped $\mathrm{ZnS}$
(b) $\mathrm{Co}^{2+}$ doped $\mathrm{ZnS}$
(c) $\mathrm{Ni}^{2+}$ doped $\mathrm{ZnS}$
(e) $\mathrm{Mn}^{2+}-\mathrm{Co}^{2+}-\mathrm{Ni}^{2+}$ tridoped $\mathrm{ZnS}$

FIGURE 20: PL emission spectra of undoped $\mathrm{ZnS}$ and $10 \%$ metal ion doped $\mathrm{ZnS}$ excited at $254 \mathrm{~nm}$.

can easily replace $\mathrm{Cd}$ ion. Furthermore, $\mathrm{CdS}$ luminescence is quenched in the case of $\mathrm{Mn}^{2+}-\mathrm{Co}^{2+}-\mathrm{Ni}^{2+}$ tridoped CdS. This is due to the replacement of cadmium ion in the host lattice by $\mathrm{Ni}$ and $\mathrm{Co}$ ions.

Figure 20 shows PL emission spectra of undoped ZnS and $10 \%$ metal ions doped $\mathrm{ZnS}$. The photoluminescence emission peak for the synthesized undoped $\mathrm{ZnS}$ nanoparticles (Figure 20-(a)) is observed at $\sim 376 \mathrm{~nm}$ which could be ascribed to a recombination of electrons at the sulfur vacancy donor level with holes trapped at the zinc vacancy acceptor level [62]. $\mathrm{Co}^{2+}$ and $\mathrm{Ni}^{2+}$ dopant ions show sharp peaks at 379 and $377 \mathrm{~nm}$, respectively (Figure 20-(b) and Figure 20-(c)). Whereas $\mathrm{Mn}^{2+}$ and tridopant ions show broad peaks at 374 and $370 \mathrm{~nm}$, respectively (Figure 20-(d) and Figure 20-(e)), they also gave new peaks at 396 and $400 \mathrm{~nm}$, respectively. This observedchange in the PL is due to the change in the band gap of the semiconductor on the addition of certain impurity element referred to as "bowing" effect [43].

The luminescence mechanism of $\mathrm{ZnS}$ nanoparticles doped with $\mathrm{Mn}^{2+}, \mathrm{Ni}^{2+}$, or $\mathrm{Co}^{2+}$ can be described as follows: the nanosized $\mathrm{ZnS}$ matrix absorbs ultraviolet photons; the electrons are excited from the valence band to the conduction band and are trapped by defects. Light emission is observed due to the recombination of the defects and the excitation states induced by the composite center of the dopant ion. When $\mathrm{Mn}^{2+}, \mathrm{Ni}^{2+}$, or $\mathrm{Co}^{2+}$ as activation ions are doped in ZnS nanoparticles, more electrons are easily excited. And the radiative recombination of luminescence processes is enhanced. Thus, the relative photoluminescence intensity of samples is dramatically increased [41]. In doped nanoparticles large number of dopant centers are concentrated near the surface of the nanoparticles, leading to give better emission efficiencies compared to that of pure $\mathrm{ZnS}$ [13].

The ion radii of $\mathrm{Zn}^{+2}, \mathrm{Mn}^{2+}, \mathrm{Co}^{2+}$, and $\mathrm{Ni}^{+2}$ are $0.074 \mathrm{~nm}$, $0.083 \mathrm{~nm}, 0.069 \mathrm{~nm}$, and $0.065 \mathrm{~nm}$, respectively [52]. MnS is far more soluble than that of $\mathrm{ZnS}$; furthermore, $\mathrm{Mn}^{+2}$ could not easily displace $\mathrm{Zn}^{+2}$ ion of the host lattice because $\mathrm{Mn}^{+2}$ ionic radius is larger than that of $\mathrm{Zn}^{+2}$. The new peak at 396 and $400 \mathrm{~nm}$ for $\mathrm{Mn}^{2+}$ doped $\mathrm{ZnS}$ and $\mathrm{Mn}^{+2}-\mathrm{Co}^{+2}$ $\mathrm{Ni}^{+2}$ tridoped $\mathrm{ZnS}$, respectively, may be due to mixed face formation. Also $\mathrm{Mn}^{2+}$ and $\mathrm{Mn}^{+2}-\mathrm{Co}^{+2}-\mathrm{Ni}^{+2}$ tridoped create points defects, which may result in the observation of new emission peaks.

In case of $\mathrm{Ni}$ and $\mathrm{Co}$ dopant, not much change in the PL peaks position is observed comparing with that of pure CdS (Figure 20-(b) and Figure 20-(c)) but the intensity increased in all of the doped $\mathrm{ZnS}$ samples. The PL intensity of the tri, Mn, Co, or Ni doped sample is about three, five, fifty, or seventy times, respectively, that of pure ZnS nanoparticles. Increasing in the PL intensity is observed because more electrons can be excited with using of $\mathrm{Mn}$, $\mathrm{Co}$, or $\mathrm{Ni}$ ions. Moreover, they induce defects and excited states to the $\mathrm{ZnS}$, which result in the $\mathrm{PL}$ in the visible region [41]. The enhancement of luminescence intensity is one of the phenomena ascribed to the size effect that luminescence intensity increases with decrease of particle size [63].

The weaker PL intensity of $\mathrm{Mn}^{+2}-\mathrm{Co}^{+2}-\mathrm{Ni}^{+2}$ tridoped $\mathrm{ZnS}$ (Figure 20-(e)) compared with that of $\mathrm{Mn}$ ion monodoped ZnS (Figure 20-(b) to Figure 20-(d)) could be attributed to the very high doping concentration (10\%) inducing concentration quenching effect [64].

\section{Conclusion}

This work reports on a facile one-step preparation of $\mathrm{Mn}^{2+}$, $\mathrm{Co}^{2+}$, or $\mathrm{Ni}^{2+}$ monodoped or tridoped CdS or $\mathrm{ZnS}$.

The successful doping of $\mathrm{Mn}^{+2}-\mathrm{Co}^{+2}-\mathrm{Ni}^{+2}$ tridoped ions into the host CdS (or $\mathrm{ZnS}$ ) was proved by the EDX spectra.

Transmission electron microscopy investigations of the synthesized samples revealed different morphologies.

Photoluminescence of $\mathrm{CdS}$ is quenched with $\mathrm{Co}^{2+}$ or $\mathrm{Ni}^{2+}$-mono-doped ions and with tridoped $\mathrm{Mn}^{2+}-\mathrm{Co}^{2+}$ $\mathrm{Ni}^{2+}$ ions, whereas $\mathrm{Mn}^{2+}$ doped $\mathrm{CdS}$ showed luminescence enhancement.

Photoluminescence of $\mathrm{ZnS}$ enhanced with doping, especially when monodoped with $\mathrm{Ni}^{2+}$ or $\mathrm{Co}^{2+}$. These compounds, therefore, offer opportunities for further technological applications; such as in electroluminescence devices, phosphors, light emitting displays, and optical sensors.

\section{Conflict of Interests}

The authors declare that there is no conflict of interests regarding the publication of this paper.

\section{References}

[1] A. Tiwaria, S. A. Khanb, and R. S. Kher, "Surface characterization and optical properties of polyphosphate capped $\mathrm{ZnS}$ nanoparticles," Advances in Applied Science Research, vol. 2, no. 1, pp. 105-110, 2011.

[2] N. M. Saeed and A. M. Suhail, "Enhancement the optical properties of zinc sulfide thin films for solar cell applications," Iraqi Journal of Science, vol. 53, no. 1, pp. 88-95, 2012. 
[3] X. Yang, D. Zhao, K. S. Leck et al., "Full visible range covering InP/ZnS nanocrystals with high photometric performance and their application to white quantum dot light-emitting diodes," Advanced Materials, vol. 24, no. 30, pp. 4180-4185, 2012.

[4] M. Geszke-Moritz, G. Clavier, J. Lulek, and R. Schneider, "Copper- or manganese-doped $\mathrm{ZnS}$ quantum dots as fluorescent probes for detecting folic acid in aqueous media," Journal of Luminescence, vol. 132, no. 4, pp. 987-991, 2012.

[5] Y. Liu, J. Hu, C. Ngo et al., "Gram-scale wet chemical synthesis of wurtzite-8H nanoporous $\mathrm{ZnS}$ spheres with high photocatalytic activity," Applied Catalysis B: Environmental, vol. 106, no. 1-2, pp. 212-219, 2011.

[6] C. Sun, J. S. H. Lee, and M. Zhang, "Magnetic nanoparticles in MR imaging and drug delivery," Advanced Drug Delivery Reviews, vol. 60, no. 11, pp. 1252-1265, 2008.

[7] M. E. Mathew, J. C. Mohan, K. Manzoor, S. V. Nair, H. Tamura, and R. Jayakumar, "Folate conjugated carboxymethyl chitosanmanganese doped zinc sulphide nanoparticles for targeted drug delivery and imaging of cancer cells," Carbohydrate Polymers, vol. 80, no. 2, pp. 442-448, 2010.

[8] H. Y. Kong, S. Kim, J. Byun, and C. Hwang, "Differential effects of cysteine and histidine-capped ZnS:Mn nanocrystals on Escherichia coli and human cells," Bulletin of the Korean Chemical Society, vol. 32, no. 1, pp. 53-58, 2011.

[9] K. Sato and H. Katayama-Yoshida, "Ab initio study on the magnetism in ZnO-, ZnS-, ZnSe- and ZnTe-based diluted magnetic semiconductors," Physica Status Solidi B, vol. 229, no. 2, pp. 673-680, 2002.

[10] C. Corrado, Y. Jiang, F. Oba, M. Kozina, F. Bridges, and J. Z. Zhang, "Synthesis, structural, and optical properties of stable ZnS:Cu,Cl nanocrystals," Journal of Physical Chemistry A, vol. 113, no. 16, pp. 3830-3839, 2009.

[11] A. E. Abken, D. P. Halliday, and K. Durose, "Photoluminescence study of polycrystalline photovoltaic CdS thin film layers grown by close-spaced sublimation and chemical bath deposition," Journal of Applied Physics, vol. 105, no. 6, Article ID 064515, 2009.

[12] N. Saravanan, G. B. Teh, S. Y. P. Yap, and K. M. Cheong, "Simple synthesis of $\mathrm{ZnS}$ nanoparticles in alkaline medium," Journal of Materials Science: Materials in Electronics, vol. 19, no. 12, pp. 1206-1208, 2008.

[13] D. Sridevi and K. V. Rajendran, "Enhanced photoluminescence of $\mathrm{ZnS}$ nanoparticles doped with transition and rare earth metallic ions," Chalcogenide Letters, vol. 7, no. 6, pp. 397-401, 2010.

[14] R. Xing and S. Liu, "Facile synthesis of fluorescent porous zinc sulfide nanospheres and their application for potential drug delivery and live cell imaging," Nanoscale, vol. 4, no. 10, pp. 3135-3140, 2012.

[15] S. Tiwari, U. K. Jain, and R. Tiwari, "High efficient ZnS:Mn thin-film electroluminescent devices," International Journal of Physics and Mathematical Sciences, vol. 2, no. 3, pp. 102-107, 2012.

[16] M. Grus and A. Sikorska, "Characterization of the absorption edge in crystalline CdS:Cu powder by use of photoacoustic and reflection spectroscopy," Physica B: Condensed Matter, vol. 266, no. 3, pp. 139-145, 1999.

[17] P. C. Pande, G. J. Russell, and J. Woods, "The properties of electrophoretically deposited layers of CdS," Thin Solid Films, vol. 121, no. 2, pp. 85-94, 1984.
[18] A. Al Bassam, A. W. Brinkman, G. J. Russell, and J. Woods, "Electrical properties of $\mathrm{Zn}_{x} \mathrm{Cd}_{1-x}$ Se," Journal of Crystal Growth, vol. 86, no. 1-4, pp. 667-672, 1990.

[19] P. P. Hankare, V. M. Bhuse, K. M. Garadkar, S. D. Delekar, and I. S. Mulla, "Chemical deposition of cubic CdSe and HgSe thin films and their characterization," Semiconductor Science and Technology, vol. 19, no. 1, pp. 70-75, 2004.

[20] T. M. Thi, L. V. Tinh, B. H. van, P. V. Ben, and V. Q. Trung, "The effect of polyvinylpyrrolidone on the optical properties of the ni-doped $\mathrm{ZnS}$ nanocrystalline thin films synthesized by chemical method," Journal of Nanomaterials, vol. 2012, Article ID 528047, 8 pages, 2012.

[21] B. Shen, H. Zhou, Z. Chen et al., "Synthesis and optoelectrochemical properties of ZnS:Mn nanocrystals," Journal of Nanoscience and Nanotechnology, vol. 12, no. 5, pp. 3931-3937, 2012.

[22] Z. Deng, L. Tong, M. Flores et al., "High-quality manganesedoped zinc sulfide quantum rods with tunable dual-color and multiphoton emissions," Journal of the American Chemical Society, vol. 133, no. 14, pp. 5389-5396, 2011.

[23] H. Lakhotiya, Gagandeep, C. Saini, A. Goyal, K. V. R. Rao, and S. L. Kothari, "Structural and optical study of ZnS nanoparticles doped with different concentration of Co," Advanced Nanomaterials and Nanotechnology, vol. 143, pp. 183-189, 2013.

[24] P. H. Borse, N. Deshmukh, R. F. Shinde, S. K. Date, and S. K. Kulkarni, "Luminescence quenching in $\mathrm{ZnS}$ nanoparticles due to Fe and Ni doping," Journal of Materials Science, vol. 34, no. 24, pp. 6087-6093, 1999.

[25] S. Kumar, N. K. Verma, and M. L. Singla, "Reflective characteristics of Ni doped ZnS nanoparticle-pigment and their coatings," Chalcogenide Letters, vol. 8, no. 9, pp. 561-569, 2011.

[26] H. Y. Acar, R. Kas, E. Yurtsever, C. Ozen, and I. Lieberwirth, "Emergence of 2MPA as an effective coating for highly stable and luminescent quantum dots," The Journal of Physical Chemistry C, vol. 113, no. 23, pp. 10005-10012, 2009.

[27] Y. M. Mo, Y. Tang, F. Gao, J. Yang, and Y. Zhang, "Synthesis of fluorescent CdS quantum dots of tunable light emission with a new in situ produced capping agent," Industrial and Engineering Chemistry Research, vol. 51, no. 17, pp. 5995-6000, 2012.

[28] S. M. Liu, F. Q. Liu, H. Q. Guo, Z. H. Zhang, and Z. G. Wang, "Surface states induced photoluminescence from $\mathrm{Mn} 2+$ doped CdS nanoparticles," Solid State Communications, vol. 115, no. 11, pp. 615-618, 2000.

[29] M. Saif and M. S. A. Abdel-Mottaleb, "Titanium dioxide nanomaterial doped with trivalent lanthanide ions of $\mathrm{Tb}, \mathrm{Eu}$ and Sm: preparation, characterization and potential applications," Inorganica Chimica Acta, vol. 360, no. 9, pp. 2863-2874, 2007.

[30] W. Baiqi, S. Xudong, F. Qiang et al., "Photoluminescence properties of Co-doped $\mathrm{ZnO}$ nanorods array fabricated by the solution method," Physica E: Low-Dimensional Systems and Nanostructures, vol. 41, no. 3, pp. 413-417, 2009.

[31] T. Kezuka, M. Konishi, T. Isobe, and M. Senna, "Preparation and properties of nanocrystalline $\mathrm{ZnS}: \mathrm{Mn}$-polymer composite films," Journal of Luminescence, vol. 87-89, pp. 418-420, 2000.

[32] N. Feltin, L. Levy, D. Ingert, and M. P. Pileni, "Magnetic properties of 4-nm Cd1-yMnyS nanoparticles differing by their compositions, y," Journal of Physical Chemistry B, vol. 103, no. 1, pp. 4-10, 1999.

[33] T. Igarashi, T. Isobe, and M. Senna, "EPR study of $\mathrm{Mn}^{2+}$ electronic states for the nanosized $\mathrm{ZnS}$ :Mn powder modified by acrylic acid," Physical Review B: Condensed Matter and Materials Physics, vol. 56, no. 11, pp. 6444-6445, 1997. 
[34] L. Levy, N. Feltin, D. Ingert, and M. P. Pileni, “Three dimensionally diluted magnetic semiconductor clusters Cd1-yMnyS with a range of sizes and compositions: dependence of spectroscopic properties on the synthesis mode," Journal of Physical Chemistry $B$, vol. 101, no. 45, pp. 9153-9160, 1997.

[35] R. N. Bhargava, D. Gallagher, and T. Welker, "Doped nanocrystals of semiconductors: a new class of luminescent materials," Journal of Luminescence, vol. 60-61, pp. 275-280, 1994.

[36] J. Cao, D. Han, B. Wang et al., "Low temperature synthesis, photoluminescence, magnetic properties of the transition metal doped wurtzite ZnS nanowires," Journal of Solid State Chemistry, vol. 200, pp. 317-322, 2013.

[37] S. P. Patel, J. C. Pivin, M. K. Patel et al., "Defects induced magnetic transition in Co doped $\mathrm{ZnS}$ thin films: effects of swift heavy ion irradiations," Journal of Magnetism and Magnetic Materials, vol. 324, no. 13, pp. 2136-2141, 2012.

[38] K. Liu, J. Y. Zhang, X. Wu et al., "Fe-doped and (Zn, Fe) codoped CdS films: could the $\mathrm{Zn}$ doping affect the concentration of $\mathrm{Fe}^{2+}$ and the optical properties?" Physica B: Condensed Matter, vol. 389, no. 2, pp. 248-251, 2007.

[39] J. K. Furdyna, "Diluted magnetic semiconductors," Journal of Applied Physics, vol. 64, no. 4, pp. R29-R64, 1988.

[40] N. S. Gajbhiye, R. S. Ningthoujam, A. Ahmed, D. K. Panda, S. S. Umare, and S. J. Sharma, "Re-dispersible $\mathrm{Li}^{+}$and $\mathrm{Eu}^{3+}$ co-doped CdS nanoparticles: luminescence studies," Pramana Journal of Physics, vol. 70, no. 3, pp. 313-321, 2008.

[41] P. Yang, M. Lü, G. Zhou, D. Yuan, and D. Xu, "Photoluminescence characteristics of $\mathrm{ZnS}$ nanocrystallites co-doped with $\mathrm{Co}^{2+}$ and $\mathrm{Cu}^{2+}$, Inorganic Chemistry Communications, vol. 4, no. 12, pp. 734-737, 2001.

[42] P. Yang, M. Lü, D. Xu et al., "Luminescence characteristics of $\mathrm{ZnS}$ nanoparticles co-doped with $\mathrm{Ni}^{2+}$ and $\mathrm{Mn}^{2+}$," Optical Materials, vol. 24, no. 3, pp. 497-502, 2003.

[43] M. J. Iqbal and M. Iftekhar, "Effect on photophysical properties of colloidal $\mathrm{ZnS}$ quantum dots by doping with cobalt, copper, and cobalt-copper mixtures," Journal of Nanoparticle Research, vol. 13, no. 5, pp. 2139-2145, 2011.

[44] G. Murugadoss, "Luminescence properties of co-doped ZnS:Ni, $\mathrm{Mn}$ and $\mathrm{ZnS}: \mathrm{Cu}, \mathrm{Cd}$ nanoparticles," Journal of Luminescence, vol. 132, no. 8, pp. 2043-2048, 2012.

[45] S. Ummartyotin, N. Bunnak, J. Juntaro, M. Sain, and H. Manuspiya, "Synthesis and luminescence properties of $\mathrm{ZnS}$ and metal (Mn, Cu)-doped-ZnS ceramic powder," Solid State Sciences, vol. 14, no. 3, pp. 299-304, 2012.

[46] L. Balakrishnan, S. Gowrishankar, P. Premchander, and N. Gopalakrishnan, "Dual codoping for the fabrication of low resistive p-ZnO," Journal of Alloys and Compounds, vol. 512, no. 1, pp. 235-240, 2012.

[47] B. Li, X. Cheng, X. Yu, L. Yan, and Z. Xing, "Synthesis and characterization of Fe-N-S-tri-doped $\mathrm{TiO}_{2}$ photocatalyst and its enhanced visible light photocatalytic activity," Advances in Materials Science and Engineering, vol. 2012, Article ID 348927, 5 pages, 2012.

[48] A. Zaleska, "Characteristics of doped- $\mathrm{TiO}_{2}$ photocatalysts," Physicochemical Problems of Mineral Processing, vol. 42, pp. 211222, 2008.

[49] L. Wang, H. Chen, D. Zhang, D. Zhao, and W. Qin, "Dual-mode luminescence from lanthanide tri-doped NaYF4 nanocrystals," Materials Letters, vol. 65, no. 3, pp. 504-506, 2011.

[50] M. Molaei, M. Marandi, E. Saievar-Iranizad et al., "Near-white emitting QD-LED based on hydrophilic CdS nanocrystals," Journal of Luminescence, vol. 132, no. 2, pp. 467-473, 2012.
[51] C. S. Pathak and M. K. Mandal, "Enhanced photoluminescence properties of $\mathrm{Mn}^{2+}$ doped ZnS nanoparticles," Chalcogenide Letters, vol. 8, no. 3, pp. 147-153, 2011.

[52] D. R. Lide, CRC Handbook of Chemistry and Physics, 2006.

[53] A. Hasnat and J. Podder, "Structural and electrical transport properties of CdS and Al-doped CdS thin films deposited by spray pyrolysis," Journal of Scientific Research, vol. 4, no. 1, pp. $11-19,2012$.

[54] P. Venkatesu and K. Ravichandran, "Manganese doped cadmium sulphide (CdS: Mn) quantum particles: topological, photoluminescence and magnetic studies," Advanced Materials Letters, vol. 4, no. 3, pp. 202-206, 2013.

[55] W. Brockner, C. Ehrhardt, and M. Gjikaj, "Thermal decomposition of nickel nitrate hexahydrate, $\mathrm{Ni}\left(\mathrm{NO}_{3}\right)_{2} \cdot 6 \mathrm{H}_{2} \mathrm{O}$, in comparison to $\mathrm{Co}\left(\mathrm{NO}_{3}\right)_{2} \cdot 6 \mathrm{H}_{2} \mathrm{O}$ and $\mathrm{Ca}\left(\mathrm{NO}_{3}\right)_{2} \cdot 4 \mathrm{H}_{2} \mathrm{O}$," Thermochimica Acta, vol. 456, no. 1, pp. 64-68, 2007.

[56] M. Maleki, S. Mirdamadi, R. Ghasemzadeh, and M. S. Ghamsari, "Effect of sulfur precursor on dimensions of onedimensional CdS nanocrystals," Journal of Materials Science and Technology, vol. 25, no. 4, pp. 462-464, 2009.

[57] J. A. Dean, Lange's Handbook of Chemistry, section 8, McGrawHill, New York, NY, USA, 1999.

[58] P. Verma, G. S. Manoj, and A. C. Pandey, "Organic cappingeffect and mechanism in Mn-doped CdS nanocomposites," Physica B: Condensed Matter, vol. 405, no. 5, pp. 1253-1257, 2010.

[59] N. Li, X. Zhang, S. Chen, X. Hou, Y. Liu, and X. Zhai, "Synthesis and optical properties of CdS nanorods and CdSe nanocrystals using oleylamine as both solvent and stabilizer," Materials Science and Engineering B, vol. 176, no. 8, pp. 688-691, 2011.

[60] A. Nag, S. Sapra, S. S. Gupta et al., "Luminescence in Mn-doped CdS nanocrystals," Bulletin of Materials Science, vol. 31, no. 3, pp. 561-568, 2008.

[61] S. M. Taheri, M. H. Yousefi, and A. A. Khosravi, “Tuning luminescence of $3 \mathrm{~d}$ transition-metal doped quantum particles: $\mathrm{Ni}^{+2}$ : CdS and $\mathrm{Fe}^{+3}$ : CdS," Brazilian Journal of Physics, vol. 40, no. 3, pp. 301-305, 2010.

[62] Y. Li, Y. Ding, Y. Zhang, and Y. Qian, "Photophysical properties of ZnS quantum dots," Journal of Physics and Chemistry of Solids, vol. 60, pp. 13-15, 1999.

[63] W. Q. Peng, G. W. Cong, S. C. Qu, and Z. G. Wang, "Synthesis and photoluminescence of $\mathrm{ZnS}: \mathrm{Cu}$ nanoparticles," Optical Materials, vol. 29, no. 2-3, pp. 313-317, 2006.

[64] T. T. Q. Hoa, N. D. The, S. McVitie et al., "Optical properties of Mn-doped ZnS semiconductor nanoclusters synthesized by a hydrothermal process," Optical Materials, vol. 33, no. 3, pp. 308314, 2011. 

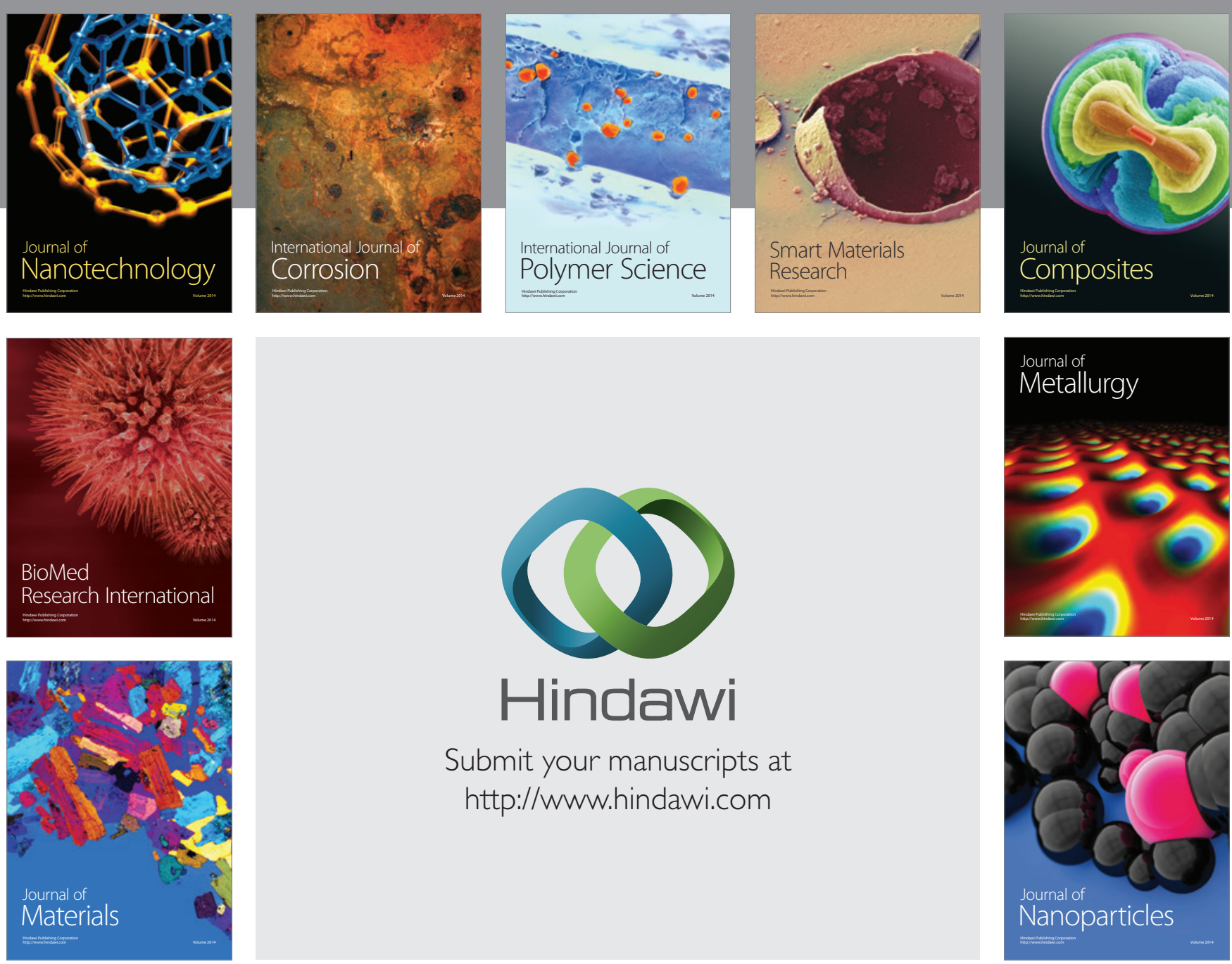

Submit your manuscripts at http://www.hindawi.com
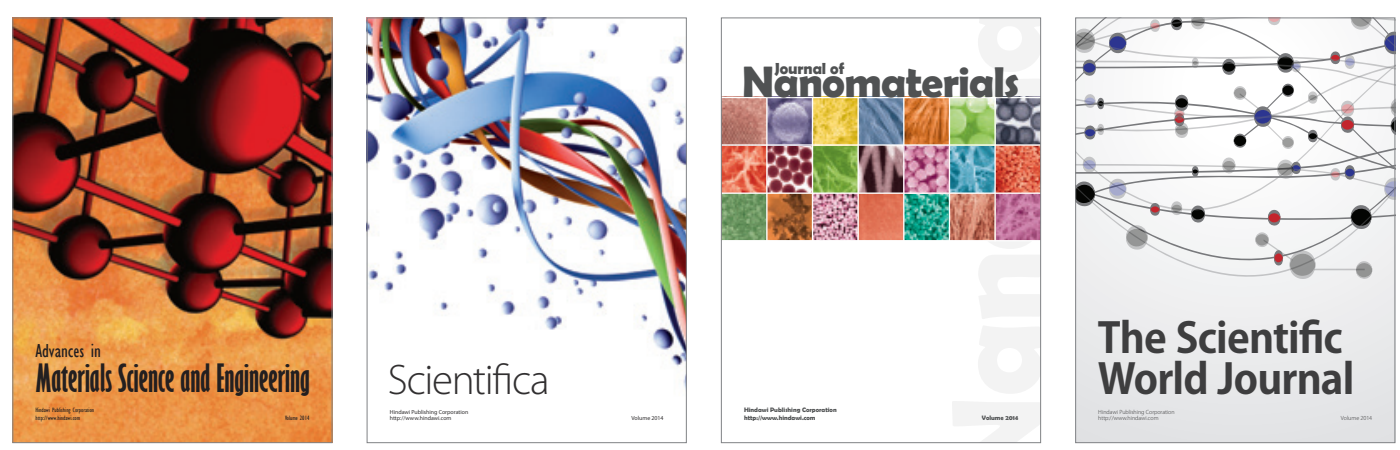

\section{The Scientific World Journal}
